\title{
Stimulation of Growth and Productivity of Onion Plants by Selenium and Growth Active Substances
}

\author{
El-Bassiony, A. M. ${ }^{1}$, S. H. Mahmoud ${ }^{1}$, S. M. El-Sawy ${ }^{1}$ and Shaymaa I Shedeed ${ }^{2}$ \\ ${ }^{I}$ Vegetable Research Department, National Research Centre, 33 El Buhouth St, Dokki, Giza, P.O. \\ 12622, Egypt. \\ ${ }^{2}$ Plant Nutrition Department, National Research Centre, 33 El Buhouth St, Dokki, Giza, P.O. 12622, \\ Egypt.
}

Received: 15 July 2020 / Accepted 12 August 2020/ Publication date: 25 Sept. 2020

\begin{abstract}
Under Egyptian conditions great efforts are devoted to research for stimulating and safe nontraditional growth materials (chemical and biological technologies in agriculture) that has a noticeable effect on plant growth characteristics, which reflects an increase in plant production. The experiments were conducted under newly reclaimed sandy soil conditions during two successive growing seasons of 2017-2018 and 2018-2019 at the Experimental and Production Station of National Research Centre, El-Noubaria region, Beheira Governorate, Egypt. A randomized complete block design with 3 replicates was used to study the effect of chitosan, seaweed, amino acid and selenium (mineral and nanoparticles) as foliar applications on vegetative growth, yield and quality as well as some chemical composition of onion plants. The results showed that spraying amino acids and mineral selenium (Se) had significant effects on plant length, number of leaves, fresh weight of leaves and bulbs, dry weight of leaves and bulbs, bulb diameter and total yield per feddan. Onion plants which received Se in the both forms; mineral and nanoparticles and amino acids produced the highest significant values of $\mathrm{N}$ and $\mathrm{K} \%$. Whereas, no significant differences were observed among the studied treatments for $\mathrm{P} \%$ in the onion leaves and bulbs in the two growing seasons. Selenium was found only in the leaves and bulbs of onion plants which treated by mineral and Nano selenium, while selenium was not detected in control, chitosan, seaweed and amino acid treatments in the both studied seasons.
\end{abstract}

Keywords: Onion, chitosan, Seaweed, amino acid, selenium, nanoparticles, foliar spray, growth, yield, chemical composition.

\section{Introduction}

Onion (Allium cepa L.) is considered the third most important vegetable crop in Egypt after tomato and potato, also it has a very high potential for exportation. Increasing the productivity of onions with high quality is an important goal for onion growers.

Chitosan and chitin are those of the most abundant polysaccharide compounds found in the nature and they were reported to improve the growth of several crops (Shaheen et al., 2019). Chitosan also can be used as a biological preparation to control or delay fungal pathogens (Borkowski et al., 2004). Borkowski et al. (2005) mentioned that spraying tomato plants with chitosan might increase the strength of these plants after a few months. Chitosan has a strong positive charge and it attracts negative molecules. Additionally, chitosan treatment stimulates plant growth. Chitosan also encouraged the growth of various crops such as soybean sprouts (Lee et al., 2005), strawberry (Abd El Mawgoud et al., 2010) and sweet pepper plants (Ghoname et al., 2010). The concentration of chitosan and the frequency of application significantly increased the growth rates of chilli and Chinese cabbage (Chandrkrachang et al., 2003). Lee et al. (2005) found that treating chitosan increases the total yield of soybean sprouts.

Amino acids are known biostimulators that have positive effects on plant growth, yield and significantly reduce injuries caused by abiotic stress (Kowalczyk and Zielony 2008). Saeed et al. (2005) reported that amino acid treatments significantly improved growth parameters for buds, fresh weight as well as pod production of soybean plants. El-Zohiri and Asfour (2009) found that, spraying amino acids at $0.25 \mathrm{ml} / 1$ resulted in a significant increase in vegetative growth expressed by plant

Corresponding Author: El-Bassiony, A.M., Vegetable Research Department, National Research Centre, 33 El Buhouth St, Dokki, Giza, P.O. 12622, Egypt. E-mail: mohsin2eg@yahoo.com 
height and plant dry weight of potatoes. The possibilities of using amino acids in modern agriculture have been studied by many researchers (Fawzy et al., 2010; Abdel- Mawgood et al., 2011; El Awadi et al., 2011). In addition, Abd El-Aal, (2012) suggested that Ananas melon plants which received amino acids mixture as a foliar application at $4 \mathrm{ml} / \mathrm{L}$ have a significant increment in vegetative growth parameters; stem length and diameter, number of leaves per plant, as well as fresh and dry weight of leaves and total leaf area. Also, Neeraja et al. (2005) revealed that application of amino acids on tomato plants increased the number of flowers and fruit setting as well as improved fruit yield.

According to the definition of plant growth stimulant that was reported by Du Jardin (2015), seaweed extract is a natural and organic stimulant for plants. Seaweed extract consists of a mixture of beneficial bioactive substances, polyphenols, polysaccharides, polyamines, dyes, free amino acids, vitamins, micronutrients and natural plant hormones (Mahmoud et al., 2019). Seaweed extract increases plant physiological activities and affects plant growth and nutrient content (Wang et al., 2007 and Taha, 2008). Selenium (Se) is a plant essential nutrient and has been proven repeatedly to promote crop growth and tolerance of abiotic stress when used in minimal amounts. However, the physiological responses of different plants differ greatly in response to the application of Se fertilizers (Irmak 2017). Selenium (Se) is required in various crops with low doses, and has an important role in hormonal balance, antioxidant reactions, and many physiological processes in plant cells. It can enhance the activities of glutathione peroxidase (GPX) that increase resistance to non-standard biological factors affecting crops (Siszar et al., 2004 and Filek et al., 2008). Se application promoted growth, production and accumulation of photosynthetic pigments in cucumbers and chives (Hawrylak- Nowak 2009 and Khalid et al., 2017). Margenot et al. (2017) reported that the cultivation of plants and crops by addition of selenium can be an effective way to produce rich nutrients thus increasing health benefits. Selenium can increase the plant's ability to resist, delay aging and increase the quality and productivity of many field and horticultural crops. Some studies have shown the benefits of Se application with respect to the productivity of some vascular plants (Hu et al., 2003; Hartikainen, 2005; Smrkolj et al., 2006; Turakainen, 2007; Lyons et al., 2009). For example, Se application increased Se concentration and productivity of both potato tubers and field pea seeds $(\mathrm{Hu}$ et al., 2003 and Turakainen, 2007). Selenium treatment had significant effect on plant growth and quality characterizes in peanut (Irmak 2017) and also cucumber seedlings (Jozwiak et al., 2016). Se has a beneficial effect on plant growth and stress tolerance by enhancing its antioxidant capacity (Djanaguiraman et al., 2005, Kong et al., 2005).

The main aim of this study was to investigate the effect of chitosan, seaweed, amino acids and selenium on vegetative growth, production and quality, as well as their effects on the chemical composition of onion plants.

\section{Materials and Methods}

Two field experiment were carried out at the experimental station of National Research Centre, at EL-Nubaria, EL-Behira Governorate, Northern Egypt, during two successive seasons 2017-2018 and 2018-2019 to study the effect of chitosan, seaweed, amino acid and selenium foliar applications on growth, yield and quality as well as some chemical composition characters of onion plants.

Onion seedlings cv. Giza 20 were transplanted at the second week of December in the two seasons. Seedlings were planted on drip irrigated ridges with $1 \mathrm{~m}$ apart and $16 \mathrm{~m}$ long with $50 \mathrm{~cm}$ between drippers. Four seedlings were planted around each dripper with $7 \mathrm{~cm}$ apart. Each plot included 5-redges and the plot area was $80.0 \mathrm{~m}^{2}$. Onion plants were supplied with the recommended dose of nitrogen ( $20 \mathrm{~g} \mathrm{~N} / \mathrm{m}^{2}$ in form of ammonium nitrate), phosphorus (12 $\mathrm{g} \mathrm{P}_{2} \mathrm{O}_{5} / \mathrm{m}^{2}$ in form of calcium super phosphate), and potassium $\left(25 \mathrm{~g} \mathrm{~K}_{2} \mathrm{O} / \mathrm{m}_{2}\right.$ in form of potassium sulphate). The normal agricultural practices required for onion production were applied as commonly followed in the farm.

The treatments were arranged as followed:

1. Control treatment "water spraying"

2. Chitosan solution was sprayed at the rates of $3 \mathrm{~cm}^{3} / \mathrm{L}$.Chitosan was obtained by using the local commercial product of ChitoCare then dissolved in tap water to obtain the targeted concentrations

3. Seaweed solution was sprayed at the rates of $5 \mathrm{~cm}^{3} / \mathrm{L}$. Seaweed extract (Kalpak) is a natural liquid extract of seaweed, and it is a global commercial product of seaweed. 
4. Amino acid was sprayed at the rates of $2 \mathrm{~cm}^{3} / \mathrm{L}$. Amino acid was obtained by using the local commercial product of Amino power. Table (1) presents the structure of chitosan, seaweed, amino acid.

5. Se Mineral: It is a normal form and it was prepared using sodium selenite $\left(\mathrm{NaSeO}_{3}\right)$. This source of selenium was imported from Hungary (Institute of Bio and Environmental Energetics, University of Debrecen). Mineral selenium was sprayed at the rates of $40 \mathrm{ppm}$.

6. Se nanoparticles: It was prepared biologically in the Soils, Water and Environment Research Institute (SWERI), Soil Micro biology Department according to Eszenyi et al., 2011. The size of selenium nano particles and other properties were measured using TEM and X-ray in Nanotechnology Lab in Agricultural Research Center, in Giza. Nano selenium was sprayed at the rates of $30 \mathrm{ppm}$. All treatments sprayed at 30 and 45 days after transplanting.

\section{Parameters recorded:}

\subsection{Vegetative growth:}

Random sample of ten plants from each plot were taken at 75 days after transplanting to record the vegetative growth parameters such as plant length $(\mathrm{cm})$, number of leaves, leaves and bulb fresh weight.

\subsection{Yield and bulb quality:}

After harvesting and curing of onion bulbs, another sample were taken to measure bulb physical characteristics such bulb diameter $(\mathrm{cm})$, and length $(\mathrm{cm})$. In the same above sample yield per feddan were calculated.

\section{Chemical constituents:}

After drying, samples of onion bulbs and leaves from each plot were used to measure dry weight of leaves and bulbs as well as bulb dry matter percentage. In the same sample the following elements are measured: $\mathrm{N}$ was determined by Kjeldahl method, $\mathrm{K}$ was determined by Flame photometer and $\mathrm{P}$ (with Spectrophotometer) as described by Cottenie et al., (1982). While, Se content was determined by atomic absorption spectroscopy as described by (Levesque and Vendette, 1971).

Table 1: The structure of chitosan, seaweed, amino acid

\begin{tabular}{|c|c|c|c|c|c|}
\hline Chitosan & & & & & \\
\hline $\mathbf{N}$ & $1000 \mathrm{ppm}$ & $\mathrm{K}_{2} \mathrm{O}$ & $500 \mathrm{ppm}$ & $\mathbf{Z n}$ & $100 \mathrm{ppm}$ \\
\hline $\mathrm{P}_{2} \mathrm{O}_{5}$ & $500 \mathrm{ppm}$ & $\mathbf{F e}$ & $100 \mathrm{ppm}$ & $\mathbf{C u}$ & $50 \mathrm{ppm}$ \\
\hline Seaweed & & & & & \\
\hline $\mathrm{N} \%$ & 1.0 & S\% & 2.2 & Alganic acids & $10-12 \%$ \\
\hline $\mathrm{K} \%$ & 18.5 & & & Glycine & $20 \%$ \\
\hline $\mathrm{Ca} \%$ & 0.17 & Auxin & $11 \mathrm{mg} / \mathrm{L}$ & Aspartic & 00 \\
\hline Mg\% & 0.42 & Citocinin & $0.03 \mathrm{mg} / \mathrm{L}$ & Glutamic & 00 \\
\hline $\mathrm{Fe} \%$ & 0.06 & Other hormones & $600 \mathrm{ppm}$ & Alanine & 00 \\
\hline Amino acid & & & & & \\
\hline Aspartic & $1.58 \%$ & Alanine & $1.05 \%$ & Lysine & $0.47 \%$ \\
\hline Threonine & $1.14 \%$ & Valine & $1.28 \%$ & Arginine & $1.55 \%$ \\
\hline Serine & $2.17 \%$ & Isoleucine & $0.67 \%$ & Proline & $2.13 \%$ \\
\hline Glutamic & $2.25 \%$ & Leucine & $0.76 \%$ & Tyrosline & $0.28 \%$ \\
\hline Glycine & $1.47 \%$ & Phenlanine & $0.81 \%$ & & \\
\hline
\end{tabular}

Experimental design and statistical analysis:

The treatments were arranged in a complete block design with three replicates. The obtained data were statistically analyzed and means separation was done using LSD test according to the method described by Gomez and Gomez (1984). 


\section{Results and Discussion}

Data in Table (2) showed that the spraying of mineral and nanoparticles selenium and some biostimulants "amino acid, seaweed and chitosan" has a significant effect on all vegetative plant characteristics; plant length, number of leaves, fresh weight of leaves, fresh weight of bulbs.

The results indicated that the highest plant length and the largest number of leaves, as well as the maximum fresh weight of the leaves and bulbs were achieved in the treatments with amino acid and selenium in the both forms with non-significant among them. While, the lowest values of the mentioned characteristics were obtained by the control treatment "water spraying".

Data in Table (3) revealed that onion plants which received amino acids and mineral selenium as a foliar application had the maximum significant values of dry weight of leaves, dry weight of bulbs (with non-significant difference with Nano selenium), bulb diameter and total yield per feddan, compared to other treatments. Whereas bulbs dry weight percentage and bulb length values didn't reach to the $5 \%$ level significant.

Table 2: Effect of chitosan, seaweed, amino acid and selenium on vegetative growth of onion plants during 2017-2018and 2018-2019 seasons.

\begin{tabular}{lcccc}
\hline & \multicolumn{3}{c}{$\mathbf{2 0 1 7 - 2 0 1 8}$} \\
\cline { 2 - 5 } Treatments & $\begin{array}{c}\text { Plant length } \\
\text { (cm) }\end{array}$ & $\begin{array}{c}\text { No. of leaves } \\
\text { /plant }\end{array}$ & $\begin{array}{c}\text { Leaves fresh } \\
\text { weight (g) }\end{array}$ & $\begin{array}{c}\text { Bulb fresh } \\
\text { weight (g) }\end{array}$ \\
\hline Control & 49.73 & 8.39 & 18.32 & 83.59 \\
Chitosan & 53.43 & 8.83 & 22.48 & 115.18 \\
Seaweed & 55.28 & 9.17 & 23.26 & 107.65 \\
Amino acid & 64.56 & 10.72 & 26.15 & 122.75 \\
Mineral selenium & 63.82 & 10.94 & 25.97 & 123.54 \\
Nanoparticles selenium & 62.82 & 10.22 & 24.87 & 120.48 \\
LSD at 5\% & 3.12 & 0.17 & 1.18 & 2.28 \\
\hline & & & $\mathbf{2 0 1 8 - 2 0 1 9}$ & \\
Control & 45.14 & 8.89 & 17.08 & 86.94 \\
Chitosan & 50.80 & 9.56 & 23.44 & 125.28 \\
Seaweed & 53.63 & 10.08 & 24.64 & 113.75 \\
Amino acid & 65.83 & 12.44 & 28.06 & 126.86 \\
Mineral selenium & 64.69 & 12.78 & 27.78 & 128.07 \\
Nanoparticles selenium & 63.16 & 11.67 & 26.10 & 123.38 \\
LSD at 5\% & 2.18 & 0.69 & 1.14 & 2.46 \\
\hline
\end{tabular}

Table 3: Effect of chitosan, seaweed, amino acid and selenium on dry weight, yield and quality of onion plants during 2017-2018and 2018-2019 seasons.

\begin{tabular}{|c|c|c|c|c|c|c|}
\hline & \multicolumn{6}{|c|}{$2017-2018$} \\
\hline & $\begin{array}{c}\text { Leaves } \\
\text { dry } \\
\text { weight (g) }\end{array}$ & $\begin{array}{l}\text { Bulbs dry } \\
\text { weight (g) }\end{array}$ & $\begin{array}{c}\text { Bulbs dry } \\
\text { weight } \\
(\%)\end{array}$ & $\begin{array}{c}\text { Bulb } \\
\text { length } \\
\text { (cm) }\end{array}$ & $\begin{array}{c}\text { Bulb } \\
\text { diameter } \\
\text { (cm) }\end{array}$ & $\begin{array}{c}\text { Total yield } \\
\text { (ton/fed.) }\end{array}$ \\
\hline Control & 4.36 & 5.65 & 6.76 & 4.93 & 6.13 & 18.51 \\
\hline Chitosan & 5.48 & 9.76 & 8.47 & 5.87 & 8.33 & 25.51 \\
\hline Seaweed & 5.83 & 9.27 & 8.61 & 5.11 & 7.89 & 23.84 \\
\hline Amino acid & 6.17 & 10.42 & 8.49 & 6.12 & 9.15 & 27.18 \\
\hline Mineral selenium & 6.10 & 10.56 & 8.55 & 6.10 & 9.22 & 27.36 \\
\hline Nanoparticles selenium & 5.86 & 10.38 & 8.62 & 5.87 & 9.02 & 26.68 \\
\hline \multirow[t]{2}{*}{ LSD at $5 \%$} & 0.37 & 0.41 & NS & NS & 0.25 & 0.50 \\
\hline & \multicolumn{6}{|c|}{ 2018-2019 } \\
\hline Control & 4.74 & 5.69 & 6.55 & 4.59 & 6.43 & 19.25 \\
\hline Chitosan & 5.45 & 9.98 & 7.97 & 6.03 & 8.79 & 27.74 \\
\hline Seaweed & 5.99 & 9.23 & 8.12 & 4.87 & 8.12 & 25.19 \\
\hline Amino acid & 6.51 & 10.99 & 8.67 & 6.41 & 10.05 & 28.09 \\
\hline Mineral selenium & 6.40 & 11.21 & 8.75 & 6.38 & 10.16 & 28.36 \\
\hline Nanoparticles selenium & 6.04 & 10.93 & 8.86 & 6.03 & 9.85 & 27.32 \\
\hline LSD at $5 \%$ & 0.26 & 0.62 & NS & $\mathrm{NS}$ & 0.18 & 0.76 \\
\hline
\end{tabular}


Furthermore, Tables (2 and 3) showed clearly the positive effect of spraying of amino acid and mineral selenium, on the vegetative growth and yield characteristics of onion plants. It is clear from Tables (2 and 3 ) to notice that the foliar application of amino acid and mineral selenium had a significant effect on all studied characteristics except the bulb length and bulb dry weight percentage. Data in (2 and 3) revealed that spraying onion plants by amino acids treatment $\left(2 \mathrm{~cm}^{3} / \mathrm{L}\right)$ produced the best results compared to the rest treatments. These results are in harmony with these obtained by Neeraja et al. (2005) who mentioned that foliar application of amino acids improved the vegetative growth parameters and yield and these may be due to amino acids providing a readily source of substances which form the protein in the living tissues. In addition, El-Desouky et al. (2011) suggested that amino acids are considered the fundamental materials in the process of protein synthesis which help plants to create tissues and organs. Other organic compounds amino acids also function in the synthesis of them; amines, purines and pyrimidine, alkaloids, vitamins and enzymes (Pratelli and Pilot, 2007). Generally, Amino acids played a role in increasing the number of flowers, fruit setting and fruit yield of tomato plants (Neeraja et al., 2005), as well as increased the vegetative growth parameters of Ananas melo plants which received amino acids at $4 \mathrm{ml} / \mathrm{L}$ (Abd El-Aal, 2012).

There is evidence that Se may improve plant productivity by improving photosynthesis, as this process is stimulated in plants by optimal supplementation with Se during the vegetative period. For example, it has been reported that the application of Se in rice positively affects photosynthesis, resulting in increased rice cereal production and concentration of Se (Zhang et al. 2014). Similar results were reported in other plant species such as potato (Turakainen et al. 2004). This can be attributed to the behavior of amino acids and mineral elements in increasing respiratory activity in the leaves, as well as chloroplast enzymes, antioxidant level and activity in plants (Sajedi et al., 2011). Foliar Se has greatly boosted the garlic bulbs (Poldma et al., 2011), onion bulbs (Kapolna et al., 2009; 2012) as well as radish flowers (Hladun et al., 2013).

Data in Tables (4 and 5) revealed the effect of foliar application of bio-stimulants and selenium in the both forms; mineral and nanoparticles on chemical composition of leaves and bulbs of onion plants. Where plants received selenium in the both forms; mineral and nanoparticles and amino acids produced the highest significant values of $\mathrm{N}$ and $\mathrm{K} \%$ in the both seasons compared to the other treatments. Whereas, no significant differences were observed among the studied treatments for $\mathrm{P} \%$ in the onion leaves and bulbs in the two growing seasons. Data in Tables (4 and 5) showed that selenium was found only in onion plants (in the leaves and bulbs) which treated by selenium in the both forms; mineral and nanoparticles, while selenium was not detected in control, chitosan, seaweed and amino acid treatments in the two experimental study.

Table 4: Effect of chitosan, seaweed, amino acid and selenium on selenium N, P and $\mathrm{K}$ in leaves of onion plants during 2017-2018and 2018-2019 seasons.

\begin{tabular}{lcccc}
\hline & \multicolumn{4}{c}{$\mathbf{2 0 1 7 - 2 0 1 8}$} \\
\cline { 2 - 5 } & $\mathbf{N \%}$ & $\mathbf{P \%}$ & $\mathbf{K \%}$ & Selenium (ppm) \\
\hline Control & 1.23 & 0.28 & 1.76 & ND \\
Chitosan & 1.30 & 0.22 & 1.71 & ND \\
Seaweed & 1.28 & 0.27 & 1.84 & ND \\
Amino acid & 1.45 & 0.25 & 1.96 & 0.0147 \\
Mineral selenium & 1.96 & 0.28 & 2.27 & 0.0086 \\
Nanoparticles selenium & 1.36 & 0.26 & 1.85 & \\
LSD at 5\% & 0.12 & NS & 0.09 & ND \\
Control & \multicolumn{3}{c}{$\mathbf{2 0 1 8 - 2 0 1 9}$} \\
Chitosan & 1.33 & 0.34 & 1.74 & ND \\
Seaweed & 1.44 & 0.25 & 1.67 & ND \\
Amino acid & 1.41 & 0.32 & 1.87 & 0.0149 \\
Mineral selenium & 1.67 & 0.29 & 2.05 & 0.0090 \\
Nanoparticles selenium & 2.05 & 0.34 & 2.52 & \\
LSD at 5\% & 1.53 & 0.31 & 1.88 & \\
\hline
\end{tabular}


Table 5: Effect of chitosan, seaweed, amino acid and selenium on selenium N, P and $\mathrm{K}$ in bulbs of onion plants during 2017-2018and 2018-2019 seasons.

\begin{tabular}{lcccc}
\hline & \multicolumn{3}{c}{$\mathbf{2 0 1 7 - 2 0 1 8}$} & \\
\cline { 2 - 5 } & $\mathbf{N \%}$ & $\mathbf{P \%}$ & $\mathbf{K \%}$ & Selenium (ppm) \\
\hline Control & 1.16 & 0.25 & 1.55 & ND \\
Chitosan & 1.35 & 0.22 & 1.53 & ND \\
Seaweed & 1.22 & 0.20 & 1.44 & ND \\
Amino acid & 1.42 & 0.21 & 1.63 & 0.0152 \\
Mineral selenium & 1.58 & 0.23 & 1.68 & 0.0088 \\
Nanoparticles selenium & 1.36 & 0.19 & 1.49 & \\
LSD at 5\% & 0.06 & NS & 0.08 & ND \\
Control & & & $\mathbf{2 0 1 8 - 2 0 1 9}$ & ND \\
Chitosan & 1.19 & 0.29 & 1.52 & ND \\
Seaweed & 1.38 & 0.20 & 1.43 & 0.0148 \\
Amino acid & 1.33 & 0.22 & 1.35 & 0.0085 \\
Mineral selenium & 1.42 & 0.23 & 1.64 & \\
Nanoparticles selenium & 1.67 & 0.26 & 1.72 & \\
LSD at 5\% & 1.41 & 0.25 & 1.49 & \\
\hline
\end{tabular}

Many investigators found that plants which treated by selenium element as a foliar application may enhance the plant production with Se compounds in concentrations of importance nutritional (Germ et al., 2007, Ozbolt et al., 2008). Moreover, Wanga et al. (2013) suggested that soil and foliar applications of Se increased the Se content in some plants without negatively effect on the N, P, K, $\mathrm{Ca}, \mathrm{Mg}, \mathrm{Fe}, \mathrm{Mn}, \mathrm{Cu}$ and $\mathrm{Zn}$ contents. While, Sors et al. (2005) found that selenium and sulfur are taken the same assimilation pathway inside the plant and Se is present in selenium amino acids such as selenomethionine and selenocysteine. Furthermore, Shedeed et al. (2018) reported that using Nano Se as a fertilizer could be increased crop yield of pea plants.

\section{Acknowledgement}

Authors would like to a great thanks for all help, efforts and supported by National Research Centre "Projects Office" Project ID No. 11030150.

\section{References}

Abd El-Aal, M.M.M., 2012. Response of Ananas Melon to foliar spray with some natural Extracts. Res. J. Agric. \& Biol. Sci., 8(2): 201-212.

Abdel-Mawgoud, A.M.R., A.M. El-Bassiouny, A. Ghoname, and S.D. Abou-Hussein, 2011. Foliar application of amino acids and micronutrients enhance performance of green bean crop under newly reclaimed land conditions. Australian Journal of Basic and Applied Sciences, 5(6):51-55.

Abdel-Mawgoud, A.M.R., A.S. Tantawy, M.A. El-Nemr and Y.N. Sassine, 2010. Growth and yield Responses of strawberry plants to Chitosan application. European Journal of Scientific Research, 39(1): 170-177.

Borkowski J., B. Dyki, A. Niekraszewicz, and H. Struszczyk, 2004. Effect of preparations Biochikol 020 PC, Tytanit, Biosept 33 SL and others on the healthiness of tomato plants and their fruiting in glasshouse. Progress on Chemistry and Application of Chitin and Its Derivatives. Monograph X, 167-173, Ed. by H. Struszczyk.

Borkowski J., B. Dyki, and A. Niekraszewicz, 2005. Effect of Biochikol 020 PC, Tytanit and other pre-parations on the growth, healthiness and the yield of tomatoes cultivated in peat substrate. 11th Workshop "New Aspects on Chemistry and Application of Chitin and its Derivatives" R7. Summares. Kazimierz Dolny. Polish Chitin Society.

Chandrkrachang, S., P. Sompongchaikul and S. Teuntai, 2003. Effect of chitosan applying in multicuture crop plantation. National Chitin-Chitosan Conference July 17-18, 2003, Chulalongkorn University, Bangkok, Thailand, pp 158-160. 
Cottenie, A., M. Verloo, L. Kiekens, G. Velghe, and R. Camerlynck 1982. Chemical analysis of plant and soil. In: Laboratory of Analytical and Agro Chemistry State Univ. Ghent Press, Ghent, Belguim.

Djanaguiraman, M., D.D. Devi, A.K. Shanker, A. Sheeba, and U. Bangarusamy, 2005. Selenium - an antioxidative protectant in soybean during senescence. Plant and Soil, 272: 77-86.

Du Jardin, P., 2015. Plant bio-stimulants: definition, concept. Main categories and regulation. Sci. Hortic. 196, 3-14.

El-Awadi, M. E., A.M. El-Bassiony, Z. F. Fawzy and M. A. El-Nemr, 2011. Response of snap bean (Phaseolus vulgaris L) plants to nitrogen fertilizer and foliar application with methionine and tryptophan. Nature and Science, 9 (5): 87-94.

El-Desouky, S.A., F.H. Ismaeil, A.L. Wanas, E.S.L. Fathy and M.M. Abd El-All, 2011. Effect of yeast extract, amino acids and citric acid on physioanatomical aspects and productivity of tomato plants grown in late summer season. Minufiya J Agric. Res., 36(4): 859-884.

El-Zohiri, S.S.M. and Y.M. Asfour, 2009. Effect of some organic compounds on growth and productivity of some potato cultivars. Annals of Agric. Sci., Moshtohor, 47 (3): $403-415$.

Eszenyi, P., A. Sztrik, B. Babka, and J. Prokisch, 2011. Elemental, Nano-Sized (100-500 nm) Selenium Production by Probiotic Lactic Acid Bacteria. International Journal of Bioscience, Biochemistry and Bioinformatics, 1 (2): $148-152$.

Fawzy, Z.F., A.M. El-Bassiony, A.G. Behairy and Y.I. Helmy, 2010. Effect of foliar spraying by some bio and organic compounds on growth, yield and chemical composition of Snap bean plants. Journal of Applied Sciences Research, 6(12): 2269-2274.

Filek, M., R. Keskinen, H. Hartikainen, I. Szarejko, A. Janiak, Z. Miszalski and A. Golda, 2008. The prote ctive role of selenium in rape seedlings subjected to cadmium stress. J. Plant Physiol., 165: 833-844.

Germ M, Kreft I, Stibilj V, Urbanc-Berčič O. 2007. Combined effects of selenium and drought on photosynthesis and mitochondrial respiration in potato, Plant Physiol. and Biochem. (Paris) 45: 162-167.

Ghoname, A.A., M.A. El-Nemr, A.M.R. Abdel-Mawgoud and W.A. El-Tohamy, 2010. Enhancement of Sweet Pepper Crop Growth and Production by Application of Biological, Organic and Nutritional Solutions. Research Journal of Agriculture and Biological Sciences, 6(3): 349-355.

Gomez, K.A., and A.A. Gomez, 1984. Statistically Procedures for Agricultural Research. 2nd Ed. John Wiely and Sons. 680.

Hartikainen, H., 2005. Biogeochemistry of selenium and its impact on food chain quality and human health. J. Trace Elem. Med. Biol., 18:309-318.

Hawrylak-Nowak, B., 2009. Beneficial effects of exogenous selenium in cucumber seedlings subjected to salt stress. Biol. Trace Elem. Res., 32: 259-269.

Hladun, K.R., D.R. Parker, K.D. Tran, and J.T. Trumble, 2013. Effects of selenium accumulation on phytotoxicity, herbivory, and pollination ecology in radish (Raphanus sativus L.). Environ. Pollut., 172: 70-75.

Hu, Q.H., J. Xu, and G.X. Pang, 2003. Effect of selenium on the yield and quality of green tea leaves harvest edit early spring. J. Agric. Food Chem., 51: 3379-3381.

Irmak, S. 2017. Effects of Selenium Application on Plant Growth and Some Quality Parameters in Peanut (Arachis hypogaea), 20(2):92-99.

Jozwiak, W., M. Mleczek and B. Politycka, 2016. The effect of exogenous selenium on the growth and photosynthetic pigments content of cucumber seedlings. Fresenius Environ. Bull., 25: 142152.

Kápolna, E., K.H. Laursen, S. Husted, and E.H. Larsen, 2012. Bio-fortification and isotopic labelling of Se metabolites in onions and carrots following foliar application of Se and 77Se. Food Chem., 133:650-657.

Kapolna, E., P.R. Hillestrøm, K.H. Laursen, S. Husted, and E.H. Larsen, 2009. Effect of foliar application of selenium on its uptake and speciation in carrot. Food Chem., 115:1357-1363.

Khalid, K.A., H.M. Amer, H.E. Wahba, S.F. Hendawy and T.M. Abd El-Razik, 2017. Selenium to improve growth characters, photosynthetic pigments and essential oil composition of chives varieties. Asian J. Crop Sci., 9: 92-99. 
Kong, L., M. Wang and D. Bi, 2005. Selenium modulates the activities of antioxidant enzymes, osmotic homeostasis and promotes the growth of sorrel seedlings under salt stress. Plant Growth Regulation, 45:155-163.

Kowalczyk, K. and T. Zielony, 2008. Effect of Aminoplant and Asahi on yield and quality of lettuce grown on rockwool. Conf. of biostimulators in modern agriculture, 7-8 Febuary 2008, Warsaw, Poland.

Lee Y.S., K. Yong-Ho and K. Sung-Bae, 2005. Changes in the Respiration, Growth, and Vitamin C Content of Soybean Sprouts in Response to Chitosan of Different Molecular Weights. Hort Science, 40(5):1333-1335.

Levesque, M., and E.D. Vendette, 1971. Selenium determination in soil and plant materials. Can. J. Soil Sci., 51: 85-93.

Lyons, G.H., Y. Genc, K. Soole, J. Stangoulis, F. Liu, and R.D. Graham 2009. Selenium increases seed production in Brassica. Plant Soil, 318.

Mahmoud, H. S.H. Dina M. Salama, A.M.M. El-Tanahy and E. H. Abd El-Samad. 2019. Utilization of seaweed (Sargassum vulgare) extract to enhance growth, yield and nutritional quality of red radish plants. Annals of Agricultural Sciences. https://doi.org/10.1016/j.aoas.2019.11.002.

Margenot, A.J., F.J. Calderon, K.W. Goyne, F.N.D. Mukome and S.J. Parikh, 2017. IR Spectroscopy, Soil Analysis Applications. In: Encyclopedia of Spectroscopy and Spectrometry, Lindon, J., G. Tranter and D. Koppenaal (Eds.). $3^{\text {rd }}$ Edn., Oxford Academic Press, UK., 448-454.

Neeraja, G., I.P. Reddy, B. Gautham, 2005. Effect of growth promoters on growth and yield of tomato cv. Marutham. Journal of Research Angrau, 33 (3): 68-70.

Ožbolt L, Kreft S, Kreft I, Germ M, Stibilj V. 2008. Distribution of selenium and phenolics in buckwheat plants grown from seeds soaked in Se solution and under different levels of UV-B radiation, Food Chemistry, 110: 691 - 696.

Põldma, P., T. Tõnutare, A. Viitak, A. Luik, and U. Moor, 2011. Effect of selenium treatment on mineral nutrition, bulb size, and antioxidant properties of garlic (Allium sativum L.). J. Agric. Food Chem. 59: 5498-5503.

Pratelli, R. and G. Pilot, 2007. Altred amino acid metabolism in glutamine dumper I plants. Plant Signal Behav., 2(3): 182-184.

Saeed, M. R., A. M. Kheir and A. A. Al-Sayed, 2005. Suppressive effect of some amino acids against Meloidogyne incognita on Soybeans. J. Agric. Sci. Mansoura Univ., 30 (2): 1097 -1103.

Sajedi, N., M. Ardakani, H. Madani, A. Naderi, and M. Miransari 2011. The effects of selenium and other micronutrients on the antioxidant activities and yield of corn (Zea mays L.) under drought stress. Physiol. Mol. Biol. Plants, 17: 215-222.

Shaheen, A. M., E. M. Ragab, Fatma A. Rizk, S.H. Mahmoud, M. M. Soliman and Nadia M. Omar, 2019. Effect of some active stimulants on plant growth, tubers yield and nutritional values of potato plants grown in newly reclaimed soil. The J. Anim. Plant Sci., 29(1): 215-225.

Shaymaa, I.S., Z.F.Fawzy and A.M. El-Bassiony, 2018. Nano and Mineral Selenium Foliar Application Effect on Pea Plants (Pisum sativum L.). Bioscience Research, 15(2): 645-654.

Siszar, J., M. Szabo, L. Erdei, L. Marton, F. Horvath and I. Tari, 2004. Auxin autotrophic tobacco callus tissues resist oxidative stress: The importance of glutathione S-transferase and glutathione peroxidase activities in auxin heterotrophic and autotrophic calli. J. Plant Physiol., 161: 691-699.

Smrklj, I.P., M. Germ, I. Kerft, and V., Staibilj. 2006. Respiratory potential and Secompoundsin Pea (Pisum sativum, L) plants grown from Se -enriched seeds. J. Exp. Bot., 57: 3595-3600.

Sors, T.G., D.R. Ellis and D.E. Salt, 2005. Selenium uptake, translocation, assimilation and metabolic fate in plants. Photosynthesis Res., 86, 373-389.

Taha, S.M., 2008. Effect of spraying with gibberellic acid and cycosil and three extracts from marine plants in some vegetative and floral traits and components of two types of strawberry (Fragaria $\times$ ananassa Duch). Salahaddin, Iraq, Faculty of Agriculture, University of Salahaddin, PhD Diss.

Turakainen, M., 2007. Selenium and its effect on growth, yield and tuber quality in potato. Academic Dissertation, Department of Applied Biology, University of Helsinki, Publication No 30 (Helsinki), 50. Frontiersin Plant Science. www.frontiersin.org. 6(356).

Turakainen, M., H. Hartikainen and M.M. Seppänen, 2004. Effects of selenium treatments on potato (Solanum tuberosum L.) growth and concentrations of soluble sugars and starch. J. Agric. Food Chem., 52:5378-5382 
Wang, D., S. Tipeng, D. Dehong, S. Liing, C. Zhen, and X. Changha, 2007. Degradation of extraction from seaweed and its complex with rare earths organ phosphorous pesticides. J. Rare Earths 25:93-99.

Wanga, J., Z. Wanga, H. Maoa, H. Zhaoa and D. Huanga, 2013. Increasing Se concentration in maize grain with soil- or foliar-applied selenite on the Loess Plateau in China. Field Crops Research 150 (2013) 83-90.

Zhang, M., S. Tang, X. Huang, F. Zhang, Y. Pang, and Q. Huang, 2014. Selenium uptake, dynamic changes in selenium content and its influence on photosynthesis and chlorophyll fluorescence in rice (Oryza sativa L.). Environ. Exp. Bot., 107:39-45. 